\title{
CITRA EMANSIPASI PEREMPUAN DALAM KISAH MAHABARATA: PELURUSAN MAKNA PERAN DAN KEBEBASAN BAGI PEREMPUAN MODERN
}

\section{WOMAN EMANCIPA TION IMAGE ON MAHABARATA STORY: AMENDING THE MEANING OF FREEDOM AND ROLE FOR THE MODERN WOMEN}

\author{
Kartika Rahmat Sari Dewi, Andayani, Nugraheni Eko Wardhani \\ Pascasarjana Universitas Sebelas Maret Surakarta \\ kartikarahmatsd@gmail.com
}

\begin{abstract}
Abstrak
Tulisan ini bertujuan untuk menemukan simbolisme dan wujud nilai emansipasi yang terdapat pada tokoh-tokoh perempuan dalam kisah pewayangan, khususnya Mahabarata. Sebagai bentuk kontruksi sosial, emansipasi memunculkan pemahaman baru pada kaum perempuan terkait dengan peran dan posisinya dalam ranah domestik maupun publik. Munculnya anggapan perempuan harus mampu tampil di depan publik mulai disetujui semua kalangan, namun di sisi lain mulai tidak diimbangi dengan pemenuhan tugas dalam ranah domestiknya. Hal tersebut dilatarbelakangi banyaknya pemahaman dan praktik yang keliru terkait makna peran dan kebebasan di kalangan perempuan, di mana semuanya terjadi dalam rangka mengusung persamaan hak, sebagai prinsip dasar dari adanya emansipasi. Fenomena ini berimplikasi pada munculnya kesenjangan antara ambisi untuk dapat totalitas berperan di ruang publik dan pemenuhan kewajiban personalnya di ranah domestik. Kajian berikut bertujuan untuk dapat menemukan nilai-nilai ideal yang berkaitan dengan peranan kaum perempuan, khususnya yang terkandung di dalam sastra Jawa klasik. Hasil dari kajian merupakan perbandingan antara makna emansipasi perempuan yang saat ini dianut di masyarakat, dengan konsep peranan perempuan yang terjabarkan dalam kisah Mahabarata.
\end{abstract}

Kata kunci: Perempuan, Emasipasi, Wayang.

Abstract

This paper aims to find the symbolism and emancipation value form found in female characters in puppet stories, especially Mahabharata. As a form of social construction, emancipation creates a new understanding for women in relation to their roles and positions in the domestic and public sphere. The emergence of women's assumption must be able to appear in public began to be approved by all circles, but on the other hand began not matched by the fulfillment of duties in the domestic realm. This is due to the many misunderstandings and misconceptions related to the meaning of roles and freedom among women, where everything happens in order to promote equality, as a basic principle of emancipation. This phenomenon has implications for the emergence of the gap between ambition to be able to play a role in the public sphere and fulfillment of personal obligations in the domestic sphere. The following study aims to find the ideal values related to the role of women, especially those contained in classical Javanese literature. The result of the study is a comparison between the meanings of women's emancipation that is currently embraced in society, with the concept of the role of women in the Mahabharata story.

Keywords: Woman, Emancipation, Puppets.

\section{Pendahuluan}

Peran dan kewajiban yang melekat pada kaum perempuan dan laki-laki sejatinya merupakan suatu kontruksi sosial yang tidak mutlak, dapat berubah sesuai perkembangan zaman dan kebutuhan. Namun, secara tidak tertulis, hal itu telah dilegalkan oleh masyarakat itu sendiri. Kontruksi sosial ini membagi tugas antara laki-laki dan perempuan secara berbeda didasarkan pada penilaian kondisi fisik dan stigma yang diberikan oleh masyarakat-pada umumnya ditentukan oleh kaum laki-lakiterhadap laki-laki dan perempuan. Laki-laki, yang dianggap lebih tangguh, berhak untuk berada di lingkungan yang lebih luas, sedangkan perempuan "hanya" diberikan wilayah seluas lingkungan rumah tangganya. Hal inilah yang kemudian melahirkan istilah gender (Kuswanti, 2009: 282). 
Masyarakat modern dan tradisional memiliki pandangan yang berbeda terkait dengan pembagian peranan antara laki-laki dan perempuan menurut versi mereka masingmasing. Masyarakat tradisional cenderung mengamini bahwa lingkungan terluas dari kaum perempuan adalah ranah domestiknya. Akan menjadi hal yang janggal ketika perempuan memiliki keterlibatan secara aktif, apalagi mendominasi diantara peranan kaum laki-laki yang cenderung berada di luar batasan lingkungan keluarga. Perempuan ideal dalam versi masyarakat tradisional ialah perempuan yang mumpuni dalam tiga perkara;kasur (tempat tidur), sumur (kamar mandi), dan dapur (kegiatan tata boga).

Perempuan dikatakan sebagai wanita seutuhnya ketika dapat membuktikan diri melalui keterampilannya mengurus keperluan rumah tangga. Hal tersebut masih dipegang kuat oleh masyarakat tradisional dengan langkah membiasakan kaum perempuan mengenal aspek sekaligus keterampilan dalam menjalankan tugas rumah tangga sejak mereka masih kanak-kanak. Perempuan dalam masyarakat tradisional mengimitasi tugas domestik mereka dengan memperhatikan peranan pada ibu atau para kerabat perempuan dalam keluarga, sehingga tertanam pemahaman bahwa tugas mereka di masa depan adalah seperti apa yang ditunjukan oleh generasi tua dalam keluarga tersebut (Wolfman, 1992: 14). Kaum perempuan ini dipersiapkan untuk mampu menjadi perempuan rumah tangga seutuhnya saat mereka memasuki fase pernikahan. Secara ringkas, pandangan tradisional meyakini dan melegalkan status perempuan berada pada konteks keluarga (Lan, 2015: 17).

Masyarakat modern memiliki pandangan yang lebih terbuka dalam menyikapi pembagian tugas antara laki-laki dan perempuan. Dimulai dari treatment yang diberikan tanpa membedakan genderkepada anak-anak. Anakanak yang berasal dari masyarakat modern telah diberikan pilihan untuk menentukan kegiatan apa yang mereka minati. Pada anak perempuan, adalah hal yang wajar manakala mereka meminati bidang yang bersifat maskulin, seperti seni bela diri, olahraga, maupun otomotif. Beranjak dewasa, kaum perempuan telah diarahkan untuk mencapai jenjang pendidikan yang lebih tinggi. Target mereka bukan lagi menjadi ibu rumah tangga, tetapi pada pencapaian karir yang didapat melalui proses pendidikan tersebut. Tugas rumah tangga setelah mereka menikah menjadi hal yang akan dipelajari secara otodidak.

Berbeda dengan laki-laki yang berangkat dari masyarakat tradisional, tuntutan dari lakilaki modern kepada perempuan tidaklah terbatas pada kemampuan mengatur rumah tangga semata. Banyak laki-laki yang mendukung penuh pencapaian karir kaum perempuan, walaupun di sisi lain tugas rumah tangga masih menjadi prioritas yang perlu diperhatikan. Bagi masyarakat modern, peranan rumah tangga bukan mutlak tugas seorang istri, tetapi merupakan tugas bersama. Dalam beberapa golongan masyarakat kelas atas, tugas rumah tangga justru dibebankan pada pihak ketiga yang memang diupah untuk melakukan hal tersebut. Pihak ketiga ini umum dikenal dengan sebutan Asisten Rumah Tangga (ART). Hal tersebut menunjukan bahwa peranan perempuan dalam masyarakat modern lebih dinamis dan tidak sepenuhnya lagi terikat pada lingkungan domestik.

Kedua kelompok masyarakat tersebut dalam membangun citra terkait peranan perempuan di dalamnya tidak terlepas dari budaya yang mereka konsumsi. Hollows (2010: 110) menyebutkan bahwa budaya populer turut mengambil bagian dalam mempengaruhi pandangan masyarakat dalam membangun citra perempuan yang ideal menurut versi mereka masing-masing. Apa yang masyarakat konsumsi sebagai sebuah pandangan ideal akan memberikan pengaruh secara signifikan terkait pembagian struktur sosial, termasuk yang berbasis gender dalam masyarakat tersebut. Budaya populer yang turut membangun konstruksi sosial tersebut salah satunya ialah karya sastra.

Masyarakat tradisional umumnya masih menjadikan karya sastra klasik sebagai acuan dalam menuntun mereka dalam membangun kontruksi sosial. Salah satunya ialah kisah-kisah pewayangan. Apa yang digambarkan dalam kisah pewayangan, akan diamini secara umum sebagai gambaran mengenai citra baik dan buruknya suatu hal. Laksono (2009: 23) berpendapat, masyarakat tradisional, khususnya suku Jawa, menjadikan wayang sebagai representasi sempurna dari dunianya. Sehingga apa yang menjadi ajaran dalam kisah-kisah pewayangan akan dijadikan imitasi dalam kehidupan sosialnya, termasuk dalam menentukan 
pemisahan peranan antara kaum laki-laki dan perempuan.

Masyarakat Jawa mengenal sosok Dewi Sembadra, Dewi Kunti, Dewi Drupadi, Dewi Setyawati, dan lainnya sebagai representasi wanita sempurna. Masyarakat tradisional memiliki paham bahwa beberapa tokoh dalam pewayangan memiliki kualitas sebagai perempuan seutuhnya sehingga perlu untuk ditiru oleh generasi-generasi selanjutnya. Kriteria ideal tersebut didasarkan pada sikap tokoh perempuan dalam kisah pewayangan yang mendukung posisi kaum laki-laki sebagai peran sentral dalam segala hal. Sehingga munculnya istilah dadi wong wadon sing manut marang guru laki (menjadi perempuan yang menurut pada suami), wong wadon kuwi marang wong lanang bebasan swarga nunut, neraka katut (posisi perempuan di hadapan suami ibarat, di neraka harus ikut, di surga hanya menurut) memberikan gambaran tentang pentingnya kaum perempuan dalam memuliakan kaum laki-laki. Masyarakat tradisional meletakan definisi mengenai perempuan ideal didasarkan pada peranannya dalam ranah domestik.

Berbeda dengan masyarakat tradisional, masyarakat modern melihat peranan kaum perempuan dari aspek pencapaiannya di ranah publik. Tokoh-tokoh dalam maupun luar negeri yang memiliki prestasi di ranah publik disebut sebagai gambaran perempuan yang ideal dan patut dijadikan sebagai inspirasi. Tokoh pemberdaya, seperti Susi Susanti, Megawati Soekarnoputri, dan Sri Wahyuni misalnya, di ranah internasional mereka mengenal pula dengan sosok Lady Diana, Benazir Butto, hingga Madona merupakan tokoh yang dijadikan standart keberhasilan dari kaum perempuan. Masyarakat modern menjadikan peranan perempuan di ranah publik menjadi salah satu prestasi yang pantas dinilai. Kewajiban dalam ranah domestik menjadi kelas kedua yang dilihat, seiring semakin gencarnya apresiasi yang diperoleh oleh kaum perempuan pada saat mereka berhasil tampil secara maksimal di sektor publik. Budaya populer masing-masing kelompok sosial memberi pengaruh tersendiri dalam pemaknaan terkait emansipasi dan hak akan kebebasan bagi kaum perempuan dari kelompok sosial tersebut.

Berkaitan dengan hal tersebut, dalam sastra Jawa, khususnya yang mengangkat kisah pewayangan, keberadaan tokoh perempuan pada umumnya jarang terangkat dalam lakon khusus. Lakon yang sering digelar dan diminati oleh masyarakat pada umumnya lakon yang terfokus pada kisah hidup tokoh laki-laki. Beberapa lakon yang terkenal di masyarakat seperti Dewa Ruci, Karna Tanding, Barathayudha, Kangsa Adu Jago, Gatotkaca Winisudha, Brubuh Alengka, Semar Mbangun Kahyangan, merupakan lakonlakon yang mengangkat tokoh wayang laki-laki sebagai tokoh inti dalam ceritanya.

Di sisi lain, lakon yang berisi kisah hidup ataupun kejadian yang berkaitan dengan tokoh perempuan cenderung jarang dipentaskan. Lakon dengan judul Alap-alap atau yang lebih dikenal sebagai lakon yang berisi mengenai proses pencarian jodoh salah seorang tokoh perempuan, dalam pagelaran ceritanya justru lebih banyak diisi dengan interaksi dan dominasi dari tokoh wayang laki-laki. Bahkan dalam lakon yang berjenis Alap-alap,tokoh wayang perempuan masih berada di bawah kekuatan hegemoni laki-laki walaupun dalam kisahnya menceritakan tentang perjodohan tokoh perempuan tersebut.

Hal tersebut secara tidak langsung memberikan doktrin kuat terhadap masyarakat penikmatnya mengenai gambaran nyata bagaimana perbedaan posisi antara tokoh laki-laki dan perempuan yang terepresentasikan melalui lakon pewayangan tersebut. Pada prosesnya, hal ini akan semakin menjauhkan kesan yang kuat pada masyarakat terhadap tokoh wayang perempuan, sehingga dapat berkurang pula apreasiasi mereka terhadap tokoh-tokoh wayang tersebut. Hal ini berkaitan dengan kuatnya pengaruh sastra dan budaya, khususnya dalam kehidupan masyarakat Jawa, dalam membentuk persepsi masyarakat penikmatnya. Demikian pula dalam wayang dan masyarakat Jawa. Di dalam wayang terdapat berbagai konsep serta model yang digunakan oleh orang Jawa untuk menginterpretasikan dunianya (Laksono, 2009: 23). Sehingga apa yang tergambar dalam pertunjukan wayang, secara langsung akan diambil sebagai acuan dalam membuat konstruksi sosial di masyarakat.

Sikap emansipasi tidak semata ditemukan secara tersurat melalui karya sastra modern, tetapi juga tersimbolkan melalui kisah pewayangan dalam budaya Jawa. Melihat posisi tokoh wayang perempuan yang cenderung tunduk pada aturan dan dominasi tokoh laki-laki, memberikan pelayanan dan pengayoman secara batiniah, hal tersebut tidak dapat diartikan 
merupakan wujud kepasrahan jiwa raga tokoh perempuan di hadapan tokoh laki-laki. Hal tersebut dapat dinilai sebagai suatu nilai emansipasi manakala memunculkan adanya pengabdian besar tokoh perempuan bagi kepentingan pihak laki-laki dan juga masyarakat luas. Karena pada dasarnya emansiapasi tidak selalu berwujud kaum perempuan yang berani tampil di depan publik, tetapi melupakan peranannya dalam ranah dosmestik (Suwarno, 2016: 131). Hakikat emansipasi yang berusaha menyejajarkan hak antara kaum perempuan dan laki-laki, dengan menyamaratakan kewajiban di segala bidang dalam sudut pandang budaya modern, akan berbeda dengan representasi emansipasi yang dikonstruksikan oleh para tokoh perempuan dalam dunia pewayangan.

Sikap emansipasi tersebut tercermin dari peranan tokoh perempuan sebagai seorang ibu sekaligus istri bagi seorang raja yang memimpin kerajaan serta sebagai satria yang diberikan kepercayaan untuk memimpin sekelompok pasukan dalam peperangan. Dalam hal tersebut, tampak sangat jelas bahwa peran tokoh perempuan menjadi sejajar manakala keberadaannya ditempatkan sebagai pihak yang dibutuhkan. Adanya usaha dan perjuangan dari tokoh wayang laki-laki untuk bisa memperistri tokoh perempuan pada lakon tertentu, secara tidak langsung menunjukan adanya penghargaan yang diberikan oleh tokoh laki-laki terkait tingginya derajat kaum perempuan. Namun, sebagian besar peranan dan kontribusi dari tokoh perempuan cenderung tertutup oleh kuatnya pengaruh tokoh laki-laki yang dilatarbelakangi oleh besarnya kekuasaan yang dimiliki. Hal ini sedikit membuka pemahaman bahwa tokoh perempuan dalam kisah pewayangan tidak dapat hanya dijadikan sebagai tokoh figuran tanpa ada kesan yang dapat diambil sama sekali, tetapi juga menjadi sosok yang merepresentasikan sikap emansipasi melalui sikap dan pembawan khas kaum perempuan. Tokoh perempuan dalam penulisan ini dipilih untuk mewakili tokoh dari berbagai strata sosial serta kedudukan yang bervariasi dalam kisah Mahabarata.

Pemaparan tersebut memberikan satu benang merah, bahwa konsep emansipasi dan peranan kaum perempuan yang terdapat dalam sastra Jawa dan pemahaman masyarakat modern memiliki makna yang berbeda. Berkaitan dengan hal tersebut, tulisan ini akan mengkaji lebih mendalam mengenai simbolisme tentang makna emansipasi dan peranan perempuan yang terkandung dalam karya sastra Jawa, yakni Mahabarata, untuk kemudian dibandingkan dengan realitas sosial yang saat ini terdapat di masyarakat modern. Relevansi hal tersebut akan digunakan sebagai alternatif referensi guna mengembalikan peranan kaum perempuan yang ideal, baik dalam sektor publik maupun dalam sektor domestik.

\section{Perempuan Modern dan Emansipasi}

Konsep emansipasi dalam konstruksi sosial di masyarakat bukan lagi menjadi hal yang baru. Pandangan ini berangkat dari adanya kemauan dan ambisi dalam menyetarakan hak antara kaum laki-laki dan perempuan dalam segala sektor kehidupan. Salah satu penyebab munculnya gerakan emansipasi ini berangkat dari fakta sosial bahwa kaum perempuan masih berada di bawah pengaruh kaum laki-laki dalam segala bidang. Fakta sejarah mencatat pula di sektor pendidikan, pemerintahan, dan hukum, kaum perempuan masih berada di kelas kedua, baik sebagai pelaku ataupun pihak yang menjadi sasaran kebijakan yang dibuat pada masanya.

Di sektor pendidikan, pada masa lalu, perempuan terkekang oleh tradisi masyarakat yang mengesahkan bahwa pendidikan dikhususkan hanya untuk kaum laki-laki semata. Perempuan dipersiapkan sebagai agen utama dalam mengurus sektor domestik, sehingga aspek pendidikan dirasa tidak perlu didalami oleh kelompok ini. Pada sektor pemerintahan, beberapa sistem pemerintahan feodal sangat mengesampingkan peranan aktif dari kaum perempuan. Kaum perempuan jarang dilibatkan dalam proses pengambilan kebijakan dan hanya berperan sebagai subjek yang menerima kebijakan yang telah dibuat oleh kaum laki-laki. Hal demikian tidak jarang banyak memunculkan intrik yang berdasarkan kebijakan pemerintahan yang telah dibuat. Montaigne (dalam Beauvoir, 2016: xvii) menyebutkan permasalahan yang muncul terkait dengan kebijakan baru dalam pemerintahan, khususnya yang berkaitan dengan kehidupan kaum perempuan, dilatarbelakangi tidak adanya transparansi dari kaum laki-laki dan pelibatan kaum perempuan dalam prosesnya.

Pada sektor hukum, Behavoir (2010: 89) menyebutkan kesenjangan dalam hal keadilan sosial terlihat manakala kesaksian pihak perempuan jarang diterima pada ruang hukum masyarakat. Proses hukum masa lalu cenderung 
menerima kesaksian dari kaum laki-laki karena dinilai lebih bersifat logika dibandingkan kaum perempuan yang cenderung menggunakan sisi emosional dalam menyampaikan suatu hal. Pembawaan kaum perempuan yang lebih mengedepankan sisi emosional tidak sepenuhnya salah. Namun, menggunakan aspek tersebut sebagai satu hal yang diperhitungkan dalam ranah hukum tentu bukan suatu hal yang patut untuk dilakukan. Mill (dalam Djarkasi, 2008) menguatkan pendapat bahwa persamaan hak antara kaum laki-laki dan perempuan di bidang hukum menjadi syarat utama menuju masyarakat yang adil.

Beberapa fakta sejarah tersebut menjadi salah satu alasan adanya kesadaran kaum perempuan dalam menuntut adanya pengakuan, khususnya dari kaum laki-laki, dalam menilai keberadan kelompok tersebut. Hal tersebut kemudian memunculkan adanya gerakan emansipasi. Gerakan emansipasi telah banyak memunculkan tokoh yang mewakili kaum perempuan pada masing-masing zamannya. Munculnya sosok Ratu dengan nama Tri Bhuawana Tungga Dewi pada masa kerajaan Majapahit (Jiz, 2011: 34), hingga kemunculan Megawati Soekarnoputri sebagai presiden perempuan pertama, menunjukan bahwa keberadaan perempuan dari masing-masing zaman memiliki potensi sebagi sosok yang berpengaruh di masyarakat. Hal tersebut semakin menyadarkan kaum perempuan, khususnya yang berasal dari masyarakat modern, untuk semakin mengembangkan kompetensinya agar mendapatkan pengakuan luas.

Peranan kaum perempuan modern di berbagi sektor publik terinspirasi dari pendahulu mereka yang juga mencapai keberhasilan di sektor yang sama. Pemahaman emansipasi sebagai persamaan hak berbasis gender mengantarkan kaum perempuan modern untuk mulai memasuki ranah publik secara lebih luas. Pengembangan karir, peningkatan status sosial, pemerolehan jenjang pendidikan tertinggi, hingga Penempatan pada posisi tertinggi hierarki pemerintahan menjadi bukti adanya gerakan nyata kaum perempuan modern dalam menunjukan diri di masyarakat. Dinamika masyarakat yang dipengaruhi oleh keberadaan kaum perempuan menunjukan perkembangan suatu negara antara lain dipengaruhi oleh banyaknya kaum perempuan yang berpendidikan dan berperan dalam kebijakaan pemerintahan (Djarkasi, 2008: 119).
Kaum perempuan modern mengembangkan kompetensinya bukan semata dalam rangka penerapan emansipasi semata, tetapi juga telah merambah pada kepentingan taraf hidupnya. Lingkungan sosial masyarakat modern yang memberikan prestise lebih kepada golongan dengan pendapatan dan kemampuan finansial lebih, menjadi salah satu faktor pendorong kaum perempuan memiliki target tertentu, baik dalam karir ataupun jenjang pendidikan. Kesuksesan dan kewibawan seseorang dinilai dan diukur dari sejauh mana dia mampu mengumpulkan materi (Hakim, 2007: 7). Berkaitan dengan hal tersebut, jenjang pendidikan dinilai sebagai sarana yang mampu meningkatkan kapasistas karir perempuan di masa depannya. Sehingga bagi kalangan perempuan modern, pendidikan menjadi salah satu prioritas utama yang harus tercapai untuk mendukung kepentingannya di ranah publik.

Pemaknaan emansipasi bagi perempuan modern yang cenderung berorientasi pada ranah publik memiliki implikasi yang nyata pada kegiatannya di ranah domestik. Kaum perempuan modern cenderung berpandangan adanya kesempatan dan persamaan hak yang mereka dapatkan, secara otomatis akan membebaskan kewajiban mereka di ranah domestiknya. Keberhasilan di sektor publik menjadi prioritas utama dibandingkan pemenuhan kewajiban pada ranah domestik. Hal tersebut tercermin dengan banyaknya kaum perempuan modern saat ini yang mempercayakan urusan domestik pada pihak lain. Munculnya salah satu profesi baru yang disebut dengan Asisten Rumah Tangga (ART), sebagai pihak yang bekerja di daerah perkotaan, menunjukan adanya pergeseran nilai mengenai pemenuhan tugas domestik dari kaum perempuan modern. Di sisi lain, keberadaan profesi baru sebagai baby sitter, menunjukan kesadaran kaum perempuan modern dalam hal keikutsertaannya dalam membina keluarga telah keluar dari hal yang menjadi prioritas. Kaum perempuan modern cenderung memilih untuk terfokus pada pencapain di sektor publik dibandingkan berkecimpung di sektor domestik.

Kondisi perempuan modern dalam menyikapi adanya emansipasi dan kebebasan dalam menentukan pilihan tersebut diperkuat oleh hasil kajian Universal Networks Internasional (dalam Lan, 2015: 23) yang menunjukan gambaran dari perempuan urban modern. Hasil dari kajian tersebut menunjukan 7 dari 10 perempuan modern berorientasi pada pencapaian keberhasilan di sektor publik. Dimulai dari 
pencapaian karir, peningkatan jenjang pendidikan, pencitraan sebagai perempuan berkelas di masyarakat, kemandirian finansial, melek teknologi, penguasaan informasi, hingga kesadaran akan rasa aman dan nyaman bagi diri sendiri. Hal tersebut menunjukan pemaknaan emansipasi bagi kaum perempuan modern sama halnya dimaknai sebagai kebebasan atau meminimalkan dari tanggung jawabnya di ranah domestik.

\section{Emansipasi dalam Pewayangan}

Bagian awal kajian ini telah menyebutkan bahwa masyarakat tradisional cenderung menggunakan kisah-kisah lama sebagai acuan dalam membuat kontruksi sosial mereka, termasuk dalam menentukan pembagian tugas antara laki-laki dan perempuan. Wayang adalah salah satu kisah yang sangat akrab di kehidupan masyarakat tradisional, khususnya yang beretnis Jawa. Beberapa tokoh pewayangan telah difungsikan sebagai perlambangan antara sifat baik dan buruk, tidak terkecuali pada tokohtokoh perempuan yang ada di dalam jalan ceritanya. Masyarakat tradisional membangun pemahaman terkait peranan perempuan tidak terlepas dari tokoh-tokoh perempuan yang ada di kisah pewayangan. Tokoh yang memberikan representasi wanita Jawa seutuhnya cenderung dijadikan sebagai teladan bagi generasi muda, khususnya anak-anak perempuan agar kelak mampu meniru segala hal baik yang ditunjukan oleh tokoh wayang tersebut.

Kisah pewayangan, khususnya Ramayana dan Mahabarata, masih mempertahankan cerita dengan setting struktur sosial dan pemerintahan feodal. Berbagai lakon yang disajikan sering menunjukan kondisi masyarakat dengan sistem kerajaan dengan seorang raja (yang cenderung diperankan oleh tokoh laki-laki) yang menjadi pemimpin negara tersebut. Hal ini berimplikasi pula pada posisi tokoh perempuan yang turut pula berperan pada kisah wayang yang sama. Terdapat banyak tokoh perempuan dalam kisah pewayangan Mahabarata. Masing-masing mewakili kaum perempuan lapisan strata sosial yang berbeda. Tokoh-tokoh tersebut pada umumnya mendapat perlakuan yang sama sebagai pihak kelas kedua yang disebabkan oleh kuatnya hegemoni tokoh laki-laki.

Berangkat dari budaya masyarakat Indonesia, khususnya yang beretnis Jawa sebagai masyarakat pemilik seni pertunjukan wayang, yang meyakini secara turun temurun kodrat kaum perempuan adalah berada di bawah kekuatan hegemoni kaum laki-laki. Pemahaman tersebut semakin diperkuat melalui kisah pewayangan, yang dalam hal ini menjadi salah satu sumber penyebaran nilai dan norma dalam budaya Jawa, dengan memberikan representasi besarnya kuasa dan pengaruh kaum laki-laki dalam mengendalikan hampir semua aspek kehidupan perempuan.

Hal ini kembali lagi jika dilihat bahwa wayang masih menggunakan sistem feodal dalam kisah pewayangan sebagai setting utamanya. Tokoh raja memiliki peranan yang lebih dominan dibandingkan ratu. Walaupun memiliki kapasitas yang sama dalam memimpin sebuah kerajaan, pada umumnya legalitas seorang raja lebih diakui, baik di masyarakat nyata maupun dalam konteks kisah pewayangan. Perbedaan posisi tersebut lantas melahirkan pembagian peran yang nyata antara tugas tokoh wayang laki-laki dan tokoh wayang perempuan dalam lakon pewayangan. Seorang tokoh lakilaki cenderung memiliki kuasa untuk menentukan apa yang akan dikerjakan dengan leluasa, sedangkan tokoh perempuan harus mengikuti aturan tidak tertulis untuk memberikan pengabdian secara utuh kepada tokoh laki-laki melalui ranah domestiknya.

Aturan tersebut pada nyatanya menjadi suatu hal yang diterima dan diakui bahkan oleh kaum perempuan itu sendiri. Namun, yang menjadi kesalahan ialah, manakala pengabdian kaum perempuan baik dalam kehidupan nyata ataupun kisah pewayangan, dinilai sebagai wujud ketidakmampuan kaum perempuan dalam memunculkan sisi emansipasi pada dirinya. Tanpa disadari, di sisi lain, keberadaan tokoh perempuan dengan stigmanya yang berada "di belakang" tokoh laki-laki justru secara psikologis dapat menjadi tokoh yang lebih sentral, bahkan mendapatkan pengakuan dari tokoh laki-laki itu sendiri. Tokoh perempuan dalam pewayangan memberikan simbolisme mengenai emansipasi bagi kaum perempuan dengan cara yang ideal. Perempuan tetap mampu berkiprah di ranah publik, memberikan kontribusi bagi banyak orang, mendukung dan mendapat pengakuan dari tokoh laki-laki, tanpa mengabaikan kewajibannya dalam ranah domestik, baik sebagai seorang istri ataupun ibu.

Kajian ini membagi peranan tokoh perempuan dalam kisah pewayangan ke dalam 
dua sektor, yakni sektor publik dan sektor domestik. Sektor domestik diwakili oleh Dewi Kunthi, Dewi Drupadi, Dewi Sembadra, dan Dewi Setyawati. Peranan kaum perempuan di sektor publik diwakili oleh Dewi Srikandhi dan Dewi Larasati. Tokoh perempuan tersebut mewakili kaum perempuan dari lapisan kelas sosial yang berbeda, tetapi tetap memiliki nilai dan kontribusi yang besar dalam kehidupan masing-masing.

\section{Emansipasi Tokoh Perempuan dalam Ranah Domestik}

Ranah domestik bagi kehidupan perempuan memiliki arti lingkungan pertama dan terdekat di kehidupannya. Lingkungan domestik dalam konteks pembagian peranan antara laki-laki dan perempuan mengarah pada lingkungan keluarga beserta dengan tugas-tugas yang ada di dalamnya. Secara adat tradisi sosial, keberadaan kaum perempuan memang dikenal lebih dekat dengan lingkungan domestik, baik dalam hal kepengurusan rumah tangga, hingga hal desain interior di sebuah rumah. Lingkungan domestik seolah menjadi tanggung jawab yang dipasrahkan kepada kaum perempuan oleh masyarakat. Diakui ataupun tidak, baik dalam masyarakat modern ataupun tradisional, kaum perempuan memang memiliki keterampilan khusus untuk bisa melaksanakan tugas di dalam lingkungan ini. Kaum perempuan dalam masyarakat modern, walaupun menggunakan kebebasannya untuk mengeksplorasi dunia publik, tetapi tetap memilih perempuanjuga untuk diupah untuk mengerjakan kepentingan domestiknya (Asisten Rumah Tangga).

Hal yang menjadi ironi adalah manakala pilihan kaum perempuan untuk terfokus dalam mengerjakan tugasnya di ranah domestik justru dianggap sebagai belenggu kebebasan oleh sekelompok masyarakat. Kaum perempuan yang memilih tugas untuk mengabdikan dirinya di lingkungan domestik, baik sebagai ibu ataupun istri, sering dianggap sebagai perempuan yang tidak memiliki profesi dan pengangguran. Tanpa disadari tugas sebagai ibu rumah tangga itu sendiri adalah sebuah profesi yang perlu diapresiasi oleh masyarakat. Hal ini terlihat pada adanya stigma pada Asisten Rumah Tangga (ART) yang dinilai sebagai profesi. ART itu sendiri sejatinya wujud dari lingkup pekerjaan kaum perempuan di ranah domestiknya, walaupun para ART ini tidak bekerja di lingkungannya sendiri.
Di sisi lain, keberadaan kaum perempuan di ranah domestik nyatanya memiliki peran sentral yang tidak bisa digantikan oleh kaum pria. Dalam hal mengatur rumah tangga, mendidik anak, memanajemen keuangan keluarga, hingga mengatur jadwal kegiatan seluruh anggota keluarga adalah sedikit dari banyak keterampilan yang umumnya hanya bisa dilakukan oleh kaum perempuan di ranah domestik. Sehingga penulis dalam hal ini dapat menyebut bahwa pengabdian di ranah domestik dapat disebut sebagai suatu emansipasi.

Dalam kisah pewayangan, wujud nyata emansipasi kaum perempuan di ranah domestiknya tersimbolkan oleh beberapa tokoh beserta posisinya pada cerita tersebut. Ada tokoh yang memainkan perannya sebagai istri, baik sebagai pendamping hidup raja atau pangeran, maupun sebagai seorang ibu bagi tokoh laki-laki. Emansipasi tokoh perempuan sebagai pendamping seorang raja diposisikan pada Dewi Kunti dan Dewi Setyawati. Kedua tokoh ini merupakan pendamping raja dari dua negara besar yang berbeda, yaitu Prabu Pandu Dewanata dari Negara Hastinapura dan Prabu Salya dari Negara Mandraka.

Dewi Kunti digambarkan sebagai sosok yang memiliki kesetiaan dan kesabaran yang besar dalam mendampingi tokoh Prabu Pandu Dewanata. Dewi Kunti mampu memiliki kebesaran hati manakala Prabu Pandu Dewanata memiliki niat untuk kembali memperistri seorang tokoh perempuan bernama Dewi Madrim sebagai istri kedua. Hal tersebut akan bertentangan dengan prinsip pengangkatan derajat perempuan manakala sikap tersebut kemudian memunculkan adanya bias gender antara kuasa tokoh Prabu Pandu dan kerelaan sikap Dewi Kunti untuk menerima praktik poligami. Namun, dalam hal ini, yang menjadi sorotan utama ialah bagaimana keikhlasan Dewi Kunti untuk tetap bisa mengabdi dalam ranah domestiknya dengan mengesampingkan perasaan pribadinya sebagai istri pertama yang telah dimadu.

Gambaran mengenai sikap dan karakter Dewi Kunti yang mencerminkan adanya nilai emansipasi tidak hanya terletak bagaimana dirinya mendukung seluruh cita-cita Prabu Pandu Dewanata. Namun, sikap itu juga terlihat ketika dirinya bersedia untuk mengasuh semua putra Prabu Pandu dan Dewi Madrim saat kedua tokoh tersebut telah meninggal dunia. Tokoh 
Pandawa Lima tumbuh menjadi satria yang tangguh dalam kesaktian dan luhur dalam budinya di bawah bimbingan dan asuhan Dewi Kunti (Purwadi, 2007:154). Tokoh ini mampu menjadi orang tua tunggal bagi kelima Pandawa tanpa membedakan kasih sayang bagi mereka semua. Hal tersebut diperkuat dengan fakta bahwa Dewi Kunti berusaha tetap mendampingi kelima putranya ketika mereka harus menjalani pengembaraan setelah diperdaya oleh Patih Sengkuni dan Kurawa dalam tragedi Balai Sigala-gala.

Pengabdian Dewi Kunti pada ranah domestiknya tersebut mewujudkan sisi emansipasi sebagai kaum perempuan yang memiliki kemandirian dan kemampuan dalam menghadapi kondisi tersulit dalam kehidupannya. Pengangkatan derajat Dewi Kunti sebagai orang tua tunggal layak diapreasiasi, mengingat begitu besarnya pengaruh yang dapat diberikan oleh seorang ibu kepada anak-anaknya. Besarnya kedudukan seorang ibu dalam sebuah ranah domestik diperkuat dengan argumentasi bahwa posisi ibu memberikan pengaruh sangat besar pada proses penanaman nilai moral dan kepribadian anakanaknya (Kartono, 2007: 18).

Emansipasi Dewi Kunti di ranah publik tergambar pada saat tokoh tersebut dipertemukan dengan salah seorang tokoh perempuan bernama Dewi Arimbi yang memiliki wujud perempuan raksasa. Dewi Arimbi datang di hadapan Raden Bratasena untuk meminta diangkat menjadi istri dari kesatria Pandhawa tersebut. Wujud raksasa yang masih bersemayam pada Dewi Arimbi menyebabkan Raden Bratasena menolak untuk menjadikannya sebagai istri. Dari kejadian tersebutlah Dewi Kunti merasa perlu untuk berupaya mengabulkan permintaan dari Dewi Arimbi. Melalui doa restu dari Dewi Kunti, Dewi Arimbi berubah menjadi seorang putri yang sangat cantik yang menjadikannya berhasil bersanding dengan Raden Bratasena.

Tokoh Dewi Kunti menempatkan dirinya dengan baik pada dua kondisi yang berbeda. Sebagai orang tua yang mampu memahami keberatan hati putranya, Raden Bratasena, yang tidak menginginkan memiliki istri seorang raksasa, sekaligus sebagai sesama perempuan yang memahami perasaan cinta tulus dari Dewi Arimbi. Tindakan itu menunjukan bahwa Dewi Kunti mampu menjadi sosok perempuan yang mengayomi dan memahami keberadaan dan keadaan orang-orang yang berada di sekitarnya, sehingga mampu mengantarnya menjadi sosok yang berkontribusi dan berperan besar bagi orang lain.

Kesejajaran Dewi Kunti dengan tokoh laki-laki ditunjukan dengan ketegasan dan keberaniannya mengucapkan sumpah untuk tidak akan berkebaya sebelum menggunakan kulit tubuh Patih Sengkuni untuk menutupi bagian atas tubuhnya. Hal ini disebabkan oleh sikap Patih Sengkuni yang berani melecehkan Dewi Kunti. Sikap tersebut menunjukan Dewi Kunti mampu menunjukkan eksistensinya di hadapan tokoh kaum laki-laki bahwa dirinya bukan sosok perempuan yang akan diam ketika diperlakukan secara diskriminatif oleh tokoh lain. Hal yang perlu digarisbawahi dari sikap yang diambil oleh Dewi Kunti ini adalah kesadaran akan kewajiban dalam menjalankan tanggung jawab di keluarganya. Dewi Kunti memberikan cerminan bagaimana seharusnya seorang perempuan memiliki kesetiaan dalam mendukung cita-cita dari suami, sekaligus selalu memantau perkembangan dari anak-anaknya.

Hal ini bisa menjadi cerminan bagi kaum perempuan modern saat dihadapkan pada pilihan, antara ambisi untuk mendapatkan prestise di sektor publik dan kewajibannya menjalankan tugas dalam hal mengasuh anak. Keberhasilan dalam ranah publik tidak dapat disetarakan dan dibandingkan dengan keberhasilan dalam mendidik seorang anak. Tindakan untuk mempercayakan pengawasan tumbuh kembang anak kepada baby sitter tidak dapat menjamin keberhasil maupun keselamatan bagi si anak itu sendiri. Hal ini terlihat dari fakta sosial dengan begitu banyaknya pihak yang diupah sebagai pengasuh bayi tersebut, justru menunjukan tindakan yang tidak bertanggung jawab, bahkan hingga menimbulkan efek buruk bagi anak yang bersangkutan.

Aspek afektif menjadi hal yang diutamakan sebagai landasan dalam melaksanakan tugas di ranah domestik. Hal ini berkaitan dengan rasa emosional yang dimiliki oleh kaum perempuan sehingga bisa memberikan perasaan nyaman terhadap anggota lainnya. Di sisi lain perasaan siap mengalahkan ego untuk dapat tampil di hadapan publik, sebagai salah satu konsekuensi kaum perempuan yang melek akan adanya persamaan hak, menjadi salah satu hal yang perlu untuk dipertimbangkan pada saat kaum perempuan memutuskan untuk terjun sepenuhnya di sektor domestik. Pada representasi 
tersebut, Dewi Kunti mengalahkan egonya dengan meluluskan permintaan Prabu Pandhu Dewanata yang akan mengambil tindakan poligami dan tetap fokus pada mendidik seluruh anaknya tanpa membedakan status antara anak kandung ataupun anak tiri.

Apabila Dewi Kunti menunjukan kemampuannya dalam menyiratkan pesan emansipasi perempuan melalui ranah domestiknya sebagai orang tua tunggal bagi kelima putranya, Dewi Setyawati menujukan emansipasinya melalui perannya sebagai seorang istri dan pendamping tokoh laki-laki secara utuh. Dewi Setyawati memiliki nama muda Dewi Pujawati, seorang putri pertapa yang diperistri oleh Prabu Salya. Nama Setyawati diberikan kepada tokoh perempuan tersebut sebagai representasi sekaligus penghargaan atas sifat setia yang dimilikinya. Dikisahkan tokoh Dewi Setyawati tidak pernah sekalipun terlibat adu pendapat maupun pertengkatan dengan suaminya (Sutardjo, 2007: 238).

Dewi Setyawati menunjukan sisi emansipasinya sebagai seorang perempuan melalui sikap dan kesetiannya dalam mendampingi tokoh Prabu Salya. Berkat kesetiaannya tersebut dirinya menjadi satu-satunya perempuan yang dijadikan istri oleh tokoh pria yang memiliki kuasa seorang raja. Tokoh Prabu Salya memiliki rasa ketergantungan dari aspek psikologi dalam bentuk perasaan cinta terhadap tokoh Dewi Setyawati. Perasaan tersebut menjadikan Prabu Salya tidak lagi merasa perlu mengambil perempuan lain sebagai seorang istri, walaupun posisinya sebagai seorang raja memiliki kehendak dan kuasa yang luas. Hal ini menjadi sesuatu yang berbeda, mengingat sistem poligami pada kisah pewayangan memberikan kebebasan tokoh raja memiliki istri lebih dari satu.

Tokoh lain yang memiliki peranan sentral dalam ranah domestik ialah Dewi Sembadra dan Dewi Drupadi. Kedua tokoh ini merupakan kerabat dekat dari Pandhawa dan cukup sering dimunculkan dalam beberapa lakon tertentu dalam epos Mahabarata. Dewi Sembadra memiliki nama muda Dewi Rara Ireng. Hal tersebut merupakan julukan bagi wujud dan kondisi fisiknya yang berkulit hitam dan bersisik pada saat tokoh ini masih berusia muda. Namun, berkat keteguhannya dalam memohon kepada Sang Pencipta, kondisi tersebut berangsur berubah yang berakhir menjadi sosok putri yang memiliki kecantikan sempurna. Dewi Sembadra merupakan representasi sempurna sebagai seorang perempuan Jawa. Tokoh ini memiliki karakter yang halus, setia, pandai menjaga kehormatan diri, dan memiliki kesabaran dalam menjalani kehidupan seharihari. Hal ini diadopsi secara kultural oleh masyarakat Jawa. Perempuan Jawa yang memiliki karakter halus dan sabar sering dikaitkan dengan gambaran tokoh Dewi Sembadra.

Dewi Sembadra menunjukan sisi emasipasinya dalam ranah domestik dengan memposisikan dirinya sebagai seorang istri yang taat dan setia kepada suaminya. Dewi Sembadra memilki citra diri yang baik terkait dengan peran dan posisinya sebagai istri Arjuna. Citra diri merupakan kesan yang didapat seorang perempuan terkait dengan dirinya sendiri (Valentine, 2005: 65). Hal tersebut menjadikan Dewi Sembadra sangat paham apa yang harus dilakukan terkait peran dan posisinya di hadapan Raden Arjuna. Tokoh ini menunjukan sisi emansipasi dalam ranah domestiknya dengan tidak pernah meninggalkan dan melaksanakan kewajiban sebagai seorang istri dan ibu. Dewi Sembadra memiliki putra yang bernama Raden Abimanyu, dari kesatria inilah trah keluarga Pandawa berlangsung. Dewi Sembadra mampu menempatkan diri sebagai ibu yang ideal bagi Abimanyu dengan memberikan kesempatan bagi tokoh tersebut untuk mengikuti jejak Arjuna sebagai satria pengelana.

Dewi Sembadra selalu memberikan bekal bagi Abimanyu berupa doa maupun pitutur dalam bertindak. Peranan Dewi Sembadra tersebut tidak lantas menghilangkan nilai kesejajaran dengan kaum pria sebagaimana yang menjadi prinsip dasar dari emansipasi. Pengabdian Dewi Sembadra di dunia domestik justru mendapatkan pengakuan dari Arjuna dan masyarakat yang mengapresiasi pertunjukan wayang. Hal ini ditunjukan dengan adanya pandangan dari masyarakat yang mengangkat tokoh Dewi Sembadra sebagai representasi perempuan Jawa yang sempurna pengabdiannya pada suami dan kehidupan rumah tangganya, sehingga pantas untuk dijadikan teladan bagi masyarakat luas. Peranan Dewi Sembadra sebagai seorang ibu dan istri memiliki pengaruh yang besar bagi orang-orang di sekitarnya. Hal ini menimbulkan adanya ketergantungan emosional dari lingkungan terhadap keberadaan tokoh Dewi Sembadra. Kartono (2007: 19) 
mempertegas keberadaan tokoh perempuan dalam lingkungan keluarga yang diiringi dengan kualitas feminisme yang unggul, instuisi yang tajam, dan kehangatan emosional akan memberikan pengaruh moril yang positif pada lingkungannya. hal inilah yang berhasil ditunjukan oleh Dewi Sembadra dalam menjalankan peranannya sebagai seorang ibu dan istri bagi keluarganya.

Sisi keberanian dari tokoh Dewi Sembadra juga terlihat pada lakon Sembadra Larung. Dewi Sembadra berani mengambil keputusan tegas untuk melukai dirinya demi mempertahankan kehormatan dirinya sebagai istri Arjuna. Hal ini dilakukan ketika tokoh Burisrawa mencoba untuk menggoda dan menyentuh Dewi Sembadra pada saat Arjuna tidak berada di tempat. Emansipasi tokoh ini tidak difokuskan pada tindakannya dalam melakukan bunuh diri, tetapi menitikberatkan pada usaha dan pengorbanannya untuk tetap setia pada satu laki-laki yang telah menjadi suaminya. Kesetiaan inilah yang menjadikan Dewi Sembadra mendapatkan kehormatan mengandung dan melahirkan putra yang akan menjadi penerus kerajaan setelah Pandawa.

Berbeda dengan Dewi Sembadra, tokoh Dewi Drupadi merupakan tokoh yang secara langsung menunjukan emansipasinya secara nyata dalam ranah domestik dan publiknya sebagai istri dari Yudhistira. Dalam ranah domestiknya, Dewi Drupadi berusaha tetap setia mendampingi Yudhistira dan kelima Pandhawa dalam segala kondisi. Hal ini ditunjukan dengan selalu terlibatnya Dewi Drupadi di semua lakon yang mengisahkan pembuangan ataupun pengasingan para Pandhawa. Apa yang berkaitan dengan Yudhistira dan Pandawa akan selalu berdampak pula pada Dewi Drupadi. Kedekatan antara Dewi Drupadi dan Pandawa tersebut bahkan memunculkan versi kisah pewayangan lain yang menggambarkan bahwa Drupadi merupakan istri dari kelima Pandawa (Abimanyu, 2014: 79).

Ketegasan Dewi Drupadi dalam menjaga hak dan kehormatan dirinya di hadapan laki-laki terlihat pula ketika dirinya dilecehkan oleh seorang tokoh Kurawa bernama Raden Dursusana. Dalam lakon Pandawa Dadu, Raden Dursusana berusaha melecehkan dengan cara menarik kain yang dikenakan oleh Dewi Drupadi. Atas kejadian penistaan tersebut, Dewi Drupadi memberikan hukuman kepada tokoh
Dursusana dengan tidak akan mengikat rambutnya sebelum tokoh Drupadi berkeramas dengan darah Dursusana. Tindakan tersebut menjadi salah satu bentuk dominasi posisi yang ditunjukan oleh Dewi Drupadi kepada tokoh Dursusana. Keberanian menentang ketidakadilan yang menjadi salah satu kriteria tindakan emansipasi berhasil dimunculkan oleh tokoh Dewi Drupadi dengan membalik keadaan dari pihak yang terdiskriminasi oleh tokoh laki-laki menjadi pihak yang memberikan hukuman kepada pihak laki-laki.

Penempatan diri perempuan sebagai sosok pendamping laki-laki belakangan ini menjadi hal yang kembali disoroti oleh publik. Konflik yang umum terjadi di ranah keluarga, selain dilatarbelakangi oleh masalah perekeonomian, juga disebabkan tidak sejalannya tujuan dari pasangan yang bersangkutan. Pola kesibukan yang tidak sama, komunikasi yang buruk, tidak adanya transparansi antarpasangan, serta kurangnya waktu berkualitas untuk bersama, menjadi beberapa penyebab munculnya konflik internal dalam keluarga. Hal tersebut sering terjadi di kalangan masyarakat modern, khususnya yang hidup di perkotaan. Kesibukan dan ambisi untuk mencapai target tertentu di sektor publik, menjadi alasan umum berkurangnya waktu bagi pasangan untuk menghabiskan waktu bersama di rumah. Di sisi lain, secara kodrati kaum laki-laki memiliki aspek psikologis ingin mendapatkan kenyamanan selama berada di rumah, khususnya dari pasangan (Beauvoir, 2016: 236). Aspek kenyaman tersebut dapat dimunculkan dalam wujud keberadaan pasangan di rumah, suasana menyenangkan, serta penyambutan yang baik pada saat pasangan kembali dari tempat kerja. Hal-hal tersebut hanya akan terwujud ketika kaum perempuan dapat menempatkan diri dengan baik selama berada di ranah domestiknya.

Keberadaan perempuan di dalam ranah domestiknya pada waktu-waktu tertentu tidak semata memberikan efek yang positif terhadap pasangan, tetapi juga memberikan pengaruh besar terhadap perkembangan psikologis anak. Keberadaan perempuan di ranah domestik, khususnya yang telah menjadi ibu, dapat memunculkan kedekatan dan ikatan yang kuat dengan si anak, sehingga pertumbuhan dan perkembangan anak pun dapat terpantau dengan baik. Hal ini diperkuat denga fakta bahwa pada masa remaja, anak-anak cenderung akan terjerumus ke dalam hal negatif jika dalam 
perjalanan menemukan jati dirinya tidak disertai dengan pengawasan langsung dari orang tua (Hakim 2007: 57). Sehingga dapat dikatakan bahwa peranan dan keberadaan kaum perempuan di ranah domestik, khususnya bagi kehidupan berkeluarga, menjadi hal yang sentral. Perempuan tidak hanya menjadi sosok yang berfungsi dalam menjalankan proses mengasuh anak - walaupun secara ideal mengasuh anak adalah tugas bersama orang tua-tetapi juga menjadi sosok yang dibutuhkan laki-laki.

Uraian tersebut menunjukan secara tersirat bahwa Dewi Seyawati berhasil menujukan kesejajarnya dengan tokoh Prabu Salya melalui pengabdian sebagai seorang istri yang dipandang sebagai perempuan sempurna di mata laki-laki. Keberanian dan kesetiaan dari tokoh Dewi Setyawati ditunjukan pula ketika terjadi perang Baratayudha dan dia mengetahui suaminya telah gugur dalam peperangan tersebut. Dewi Setyawati memilih untuk melakukan bela pati (bunuh diri) di samping jenazah suaminya untuk menunjukkan kesetiaan dirinya dalam mendampingi Prabu Salya di segala kondisi.

Uraian antara peranan Dewi Kunti dan Dewi Setyawati dalam kacamata emansipasi terkadang masih dinilai sebagai suatu pilihan yang tidak sejalan dengan konsep tersebut. Konsep emansipasi, yang berwujud terbukanya kesempatan untuk berkiprah di ranah publik, menjadikan stigma kaum perempuan yang berada di ranah domestik dinilai sebagai suatu pilihan yang kurang sepaham. Hal inilah yang menjadi acuan perempuan modern untuk memprioritaskan kesuksesan di luar, tetapi justru melalaikan betapa pentingnya peranan mereka di ranah keluarga. Apa yang tersimbolkan oleh tokoh Dewi Kunti dan Dewi Setyawati membuka pemahaman baru, bahwa peranan perempuan di dalam keluarga hakikatnya memberikan pengaruh yang luar biasa besar, tidak semata bagi anak dan pasangan, tetapi juga tentang keberlangsungan rumah tangga yang bersangkutan.

Dewi Sembadra dan Dewi Drupadi menunjukan ketegasan mereka dalam menjaga harga diri dan kesetiaan mereka saat dihadapkan pada pilihan mereka untuk mengabdikan diri di ranah domestik masing-masing. Apa yang ditunjukan Dewi Sembadra dan Dewi Drupadi tersebut memberikan perbandingan bagi kondisi masyarakat saat ini, khususnya masyarakat modern, ketika kesetiaan menjadi sesuatu yang mulai hilang dari nurani masing-masing. Perceraian yang disebabkan oleh hadirnya orang ketiga menjadi hal yang biasa terjadi di masyarakat dewasa ini. Fenomena tersebut menunjukan mulai hilangnya kesadaran akan pentingnya peranan kaum perempuan yang didukung oleh laki-laki dalam memprioritaskan kewajibannya di ranah domestik masing-masing.

\section{Emansipasi Perempuan di Ranah Publik}

Ranah publik dalam konsep emansipasi dapat diibaratkan sebagai tujuan dari adanya konsep dan gerakan kesetaraan gender tersebut dibentuk. Kesempatan untuk dapat bergerak, mencoba memperluas relasi, mendukung peningkatan karir, dan menambah pengalaman, sebagai suatu hal yang pada awalnya hanya untuk kaum laki-laki, semenjak gerakan emansipasi terwujud, menjadi hal yang juga dapat dirasakan oleh kaum perempuan. Melalui peran aktifnya dalam ranah publik, kaum perempuan cenderung menemukan kepercayaan dirinya kembali sehingga dianggap mampu sebanding dengan kaum laki-laki, baik dalam hal pencapaian ataupun kontribusi yang diberikan.

Kesempatan untuk dapat berpartisipasi secara aktif dalam ranah publik, yang pada awalnya difungsikan sebagai persamaan hak antara kaum laki-laki dan perempuan, belakangan mengalami pergeseran makna. Kompetensi kaum perempuan yang kian meningkat dengan adanya sarana dan prasarana di dunia publik, mulai memunculkan arogansi yang berujung pada persaingan tidak sehat hingga stigma negatif yang diberikan kepada kaum laki-laki. Kurniawan (2010: 57), menyebutkan kondisi dunia publik yang membuka kesempatan bagi semua kalangan tanpa membedakan gender, cenderung menggiring kaum wanita ke arah yang berkebalikan dari tujuan awal terbentuknya emansipasi. Masuknya nilai-nilai yang bersifat hedonisme menjadi salah satu indikator kaum perempuan berhasil mendapatkan pengakuan sekaligus keberhasilannya di ranah publik. Munculnya kaum-kaum sosialita yang cenderung dalam kelompoknya tidak terdapat kaum pria, menujukan kaum wanita dapat berdiri tanpa harus berdampingan dengan lawan gendernya tersebut. Padahal makna kesetaran gender ialah setara dalam artian yang seimbang dalam hal kesempatan, sehingga posisi kaum laki-laki bukan dianggap sebagai pesaing tetapi sebagai partner, baik di ranah domestik maupun publik. 
Pergeseran makna emansipasi yang berujung pada kebebasan kaum perempuan di ranah publik juga terlihat saat kaum perempuan dihadapkan pada kelompoknya sendiri dalam satu tujuan yang sama. Alih-alih bekerja sama guna menunjukan kompetensinya sebagai kaum perempuan beremansipasi, hal yang tampak justru mengarah pada persaingan tidak sehat demi mendapatkan posisi yang diinginkan. Dalam masyarakat modern, hal semacam ini cenderung terjadi pada kaum perempuan yang bekerja disebuah instansi yang menerapkan kebijakan peningkatan jabatan berdasarkan kontribusi dari pegawainya. Persaingan antargender dan antarkaum perempuan guna mendapatkan pengakuan publik menjadi salah satu hal yang perlu digarisbawahi sebagai implikasi keterlibatan perempuan di sektor tersebut.

Kisah-kisah dalam pewayangan telah menunjukan simbolisme dari kaum perempuan yang berhasil memasuki ranah publik di tengah kuatnya feodalisme yang ada dalam lakon-lakon wayang yang digelar. Keberadaan tokoh perempuan tersebut dalam ranah publik tersebut tidak semata menunjukan kesetaraannya dengan kaum laki-laki, tetapi juga menunjukan kompetensinya dalam menjalin kerjasama dengan banyak pihak, sehingga memunculkan penghargaan dari tokoh laki-laki. Beberapa tokoh perempuan yang dikisahkan menjadi bagian dari aktifitas "di luar keraton" dalam kisah pewayangan ialah Dewi Srikandhi dan Dewi Larasati. Kedua tokoh ini berhasil memiliki kontribusi besar dalam bidang militer.

Dewi Srikandhi merupakan salah satu tokoh pewayangan yang lazim dijadikan simbolisme perempuan mandiri yang sejajar dengan tokoh laki-laki. Dewi Srikandhi memiliki keterampilan yang baik dalam hal olah senjata, khususnya pedang dan senjata panah. Dewi Srikandhi dalam pewayangan sering digambarkan sebagai tokoh yang tegas, memiliki kedisiplinan tinggi, dan mampu bersiaga kapanpun dibutuhkan (Sutardjo. 2006: 18). Beberapa lakon pewayangan memberikan representasi Dewi Srikandhi sebagai sosok putri yang memiliki integritas tinggi, baik dalam membela kedaulatan daerahnya maupun menjaga keselamatan keluarganya.

Sebagai sebuah representasi perempuan yang memiliki keterampilan di bidang yang cenderung ditekuni oleh kaum laki-laki, dalam beberapa kelompok masyarakat, Dewi Srikandhi sering dipersepsikan sebagai lambang dari budaya LGBT, khususnya dalam praktik Biseksual. Hal tersebut diperkuat dengan adanya salah satu lakon wayang yang mengisahkan Dewi Srikandhi menjalani proses pergantian kelamin, sehingga bertransformasi ke wujud tokoh laki-laki yang bernama Bambang Kandhidhawa. Sosok perubahan fisik Dewi Srikandhi ini juga dikisahkan memiliki anak yang kelak justru tewas di tangan Arjuna, yang bernama Prabu Niwatakawaca (Purwadi, 2007: 140).

Berkaitan dengan hal tersebut, penulis dalam menyikapinya memilih untuk kembali melihat wayang sebagai sebuah transformasi kehidupan manusia, khususnya dalam budaya Jawa. Setiap kisah yang disajikan merupakan gambaran mengenai kondisi sosial yang ada pada masyarakat pemiliknya. Tokoh Srikandhi sebagai salah satu tokoh wayang dengan pembawaan yang dalam bahasa masyarakat modern disebut dengan tomboy, sejatinya tetap memiliki sisi gelap yang tidak seharusnya dijadikan teladan bagi masyarakat pemiliknya. Hal tersebut dapat dilihat dari sudut pandang dekontruksi, bahwa pada setiap tokoh yang ada pada pewayangan, baik dalam Ramayana maupun Mahabarata, memiliki sisi baik dan buruk, bahkan pada tokoh yang dijadikan sebagai perlambangan kebaikan secara universal, seperti Rama dan para satria Pandhawa. Keberadaan tokoh Srikandhi yang dipersepsikan sebagai lambang dari adanya praktik biseksual dalam beberapa kelompok masyarakat, sejatinya kembali lagi pada penangkapan makna dari sebuah karya sastra yang bersifat subjektif yang ada di masyarakat.

Berkaitan dengan konteks kesetaraan gender, sisi emansipasi yang ditunjukan oleh Dewi Srikandhi ialah bagaimana tokoh ini dipercaya untuk memimpin pasukan perang Pandawa dan berhasil mengalahkan senopati dari pihak Kurawa pada saat terjadi perang Barathayudha. Berhasilnya Dewi Srikandhi dalam menunjukan kemampuannya dalam ranah publik sebagai seorang prajurit perempuan, menunjukan bahwa kungkungan budaya keraton yang notabene mewajibkan seorang putri untuk tunduk pada aturan dan hegemoni laki-laki, tidak berlaku ketika sosok perempuan memiliki keinginan yang kuat untuk bisa bergerak secara lebih produktif.

Kepercayaan dari tokoh Arjuna dan Pandawa yang lain terkait integritas tokoh Dewi 
Srikandhi dalam memimpin pasukan Pandawa merupakan salah satu wujud pengakuan yang diberikan sekelompok laki-laki pada satu perempuan. Pengakuan tersebut menunjukan bahwa Dewi Srikandhi berhasil menyetarakan posisi dirinya dengan tokoh satria laki-laki yang lain. Konstruksi egaliter inilah yang berhasil diraih oleh Dewi Srikandhi dalam kiprahnya di lakon wayang Mahabarata. Hal tersebut berimplikasi pada populernya sebutan Srikandhi di masyarakat Indonesia yang menunjuk pada seorang atau sekelompok perempuan yang mampu memberikan kontribusi besar dalam lingkungannya. Hal tersebut diperkuat oleh pendapat Sutardjo (2006: 189) perempuanperempuan yang berani menentang ketidakadilan, terutama yang mengenai bangsa Indonesia, akan cenderung mendapatkan sebutan sebagai Srikandhi.

Hal demikian terlihat pula dari banyaknya kiprah kaum perempuan di masa modern ini yang berhasil menjadi bagian dari agen perubahan sehingga keberadaannya tidak dipandang berbeda dengan kaum laki-laki. Kerjasama yang terjalin antara Dewi Srikandhi dengan Raden Arjuna dalam perang Baratayuda menunjukan pula gambaran mengenai sikap kaum perempuan yang tidak terbutakan oleh kebebasan yang diperoleh dari adanya emansipasi. Dewi Srikandhi melihat tokoh laki-laki yang ada disekitarnya sebagai bagian dari partner hidup yang dapat memberikan support dalam mencapai tujuan bersama.

Hal ini memiliki berbanding terbalik dengan kondisi sosial yang ada di masyarakat modern. Kemunculan emansipasi justru mengubah cara pandang kaum perempuan dalam menilai keberadaan kaum laki-laki. Sehingga kesadaran akan kesetaraan hak sebagai sebuah kesempatan untuk bekerja sama dan melengkapi satu sama lain berubah menjadi stigma persaingan antargender dalam segala aspek kehidupan.

Berbeda dengan Dewi Srikandhi yang berdarah bangsawan, Dewi Larasati merupakan perempuan biasa yang berasal dari sebuah desa Widarakandang. Kehidupan pedesaan membentuk kepribadian Dewi Larasati menjadi sosok perempuan yang sederhana tetapi memiliki kemauan yang tinggi untuk dapat belajar. Sisi emansipasi dari tokoh Dewi Larasati ditunjukan melalui ranah publiknya, dengan mendapatkan pendidikan dan pelatihan dalam mengolah senjata. Dalam lakon Srikandhi Maguru Manah,
Dewi Larasati dipercaya kemampuannya oleh Arjuna untuk bisa menandingi kemampuan tokoh Dewi Srikandhi dalam memanah. Keunggulan Dewi Larasati dalam bertanding panah dengan Dewi Srikandhi, yang merupakan kerabat berdarah biru, menyimbolkan bahwa strata sosial yang berbeda bukan menjadi halangan bagi Dewi Larasati untuk memiliki kelebihan dibandingkan perempuan dengan darah bangsawan yang lain.

Dewi Larasati mampu memunculkan emansipasinya sebagai perempuan yang sejajar dengan tokoh laki-laki dengan menunjukan keterampilannya dalam berolah senjata. Kesempatan dalam menerima pelatihan dan pendidikan kemiliteran ini menunjukan pesan tersirat bahwa seorang perempuan tidak selamanya terkungkung dalam ranah domestiknya tanpa berani mengambil kesempatan untuk berkiprah secara bebas di luar lingkungannya yang cenderung patriakal. Kesejajaran antara Dewi Larasati dengan kaum laki-laki ditunjukan dengan adanya pengakuan dari tokoh Arjuna terkait dengan kemampuan Dewi Larasati dalam olah senjata, dengan mengangkatnya sebagai lawan bagi Dewi Srikandhi pada lakon Srikandhi Maguru Manah.

Sikap Dewi Larasati dalam mengusahakan cita-cita tanpa memandang latar belakang hidupnya, seolah kembali mengingatkan kita pada perjuangan pelopor pergerakan emansipasi di Indonesia, R.A. Kartini. Pada masyarakat modern, sosok Dewi Larasati menjadi salah satu simbol pentingnya kaum perempuan memiliki rasa optimisme dan insiatif dalam memperjuangkan keinginannya. Hal ini berangkat dari fakta adanya kaum perempuan, khususnya dalam taraf usia remaja, justru memilih terbawa arus modernisasi pada usia yang masih dini. Budaya hedonisme dan materialisme membentuk mental para kaum remaja perempuan, khususnya yang tinggal di perkotaan menjadi sosok yang menomorduakan persiapan menempuh masa depannya. Gambaran sosial yang menunjukan dunia gemerlap malam (DUGEM), yang saat ini menjadi lumrah dikenal oleh remaja, penyalagunaan narkoba, lunturnya rasa bangga terhadap budaya sendiri, adalah segelintir dari pemaknaan yang keliru tentang partisipasi di ranah publik.

Dalam hal ini dapat dikatakan bahwa Dewi Srikandhi dan Dewi Larasati memberikan cerminan mengenai sikap perempuan yang memaknai partisipasi aktif di ranah publik sebagai kesempatan untuk memberikan kontribusi 
yang positif bagi masyarakat luas. Kedua tokoh ini menunjukan bahwa emansipasi tidak bermakna kaum perempuan harus memandang laki-laki sebagai rival, tetapi menempatkan mereka sebagai rekan kerja yang kontributif. Hal tersebut menjadikan kedua tokoh ini mendapatkan pengakuan publik akan integritas dan kemampuan mereka.

Kesamaan antara Drupadi, Sembadra, dan Dewi Kunti terletak pada keberanian ketiga tokoh tersebut dalam menentang penindasan yang berbasis gender oleh para tokoh laki-laki. Ketiganya mampu menunjukan keberanian dalam menentang tekanan dan ancaman yang dilakukan oleh tokoh laki-laki terhadap diri mereka. Dewi Kunti dan Drupadi menentang diskriminasi berbasis gender dengan menjatuhkan kutukan kepada tokoh Patih Sengkuni dan Dursusana, sedangkan Dewi Sembadra memberikan pengorbanan demi menjaga kehormatan dirinya pada saat akan dilecehkan oleh tokoh Burisrawa. Ketiga tokoh tersebut sekaligus Dewi Setyawati mewakili kaum perempuan yang mampu menunjukan kompetensi dirinya untuk bisa sejajar dengan kaum laki-laki bahkan pada saat mereka terikat kewajiban sebagai pihak sentral yang harus sepenuhnya berada di ranah domestiknya. Pengabdian keempat tokoh tersebut pada gilirannya memunculkan pengakuan dan penghormatan dari kaum laki-laki. Kesejajaran yang ditunjukan oleh keempat tokoh tersebut tidak dengan memandang tokoh laki-laki sebagai pihak sentral, tetapi dengan menunjukan kepada tokoh laki-laki bahwa kaum perempuan juga memiliki kedudukan yang sama dalam menuntut dan membela harga diri yang bersifat prinsipil di hadapan kaum laki-laki.

Perbedaan antara laki-laki dan perempuan yang diciptakan oleh lingkungan (nurture) tidak selamanya menjadi pagar batas bagi kaum perempuan untuk menunjukan eksistensinya melalui jasanya dalam lingkungan domestik. Semua bentuk pengabdian perempuan dalam rumah tangga, baik sebagai ibu ataupun istri, seyogianya menjadi salah satu indikator berhasilnya kesetaraan derajat antara kaum perempuan dan laki-laki. Dalam kontruksi teologi sekalipun keberadaan perempuan yang terbatas pada ranah domestik dapat menjadi salah satu bentuk emansipasi yang bersifat egaliter.

Dewi Srikandhi dan Dewi Larasati memberikan representasi mengenai bagaimana kaum perempuan mampu menunjukan kesetarannya di ranah publik dengan berkesempatan tampil untuk melakukan hal yang bersifat maskulin. Emansipasi kedua tokoh ini terlihat manakala mereka berhasil berkiprah melalui bidang yang sering digeluti oleh kaum laki-laki. Tidak ada tokoh perempuan dalam Mahabarata yang memiliki keterampilan olah senjata kecuali sosok Dewi Srikandhi dan Dewi Larasati.

Dewi Larasati berhasil menunjukan kemampuannya melewati batas tradisi yang membelenggunya sebagai kaum perempuan dengan berhasil menjadi seorang pemanah yang setara dengan Arjuna. Kemampuan Dewi Larasati diakui oleh Arjuna dengen menjadikannya lawan tanding bagi Dewi Srikandhi. Di sisi lain, Dewi Srikandhi berhasil menunjukan prestasinya sebagai kaum perempuan pemberdaya dengan memegang posisi sebagai senopati pada perang Baratayudha. Pada perang tersebut, Dewi Srikandhi berhasil mengalahkan Resi Bisma sebagai pemimpin pasukan dari pihak Kurawa. Tindakan tersebut menunjukan Dewi Srikandhi patut dipertimbangkan sebagai sosok perempuan yang sejajar dengan kaum laki-laki.

\section{Penutup}

Berkembangnya pola pikir kaum perempuan ditambah semakin kuatnya pengaruh westernisasi dalam lingkungan masyarakat menimbulkan pemahaman serta praktik dari emansipasi perempuan yang bergeser dari makna substansinya. Emansipasi mulai dipandang sebagai proses untuk melawan sekaligus mengurangi dominasi peran kaum laki-laki dalam segala aspek kehidupan. Kaum laki-laki dipandang bukan sebagai rekan, tetapi lawan. Hal tersebut memicu tindakan kaum perempuan yang giat mengkampanyekan dirinya secara total di depan publik sebagai sosok yang mandiri tanpa ketergantungan, hingga mengurangi kesadaran bahwa keberadaan kaum laki-laki dan perempuan adalah fitrah yang sali melengkapi satu sama lain. Bergesernya pemahaman akan makna emansipasi tersebut menimbulkan kecenderungan menurunnya kesadaran kaum perempuan terkait dengan peran yang tidak bisa digantikan oleh kaum laki-laki, yakni tugas dalam ranah domestik.

Seni pertunjukan wayang sebagai produk dari budaya bangsa Indonesia mencoba untuk kembali menyadarkan kaum perempuan mengenai tanggung jawab dan peran sentralnya 
sebagai sosok yang ideal, yang mampu menjadi agen aktif dalam masyarakat tanpa melupakan kewajiban utama dalam rumah tangganya. Kajian terkait kisah Mahabarata dan relevansinya dengan emansipasi perempuan diantaranya sebagai berikut. Pertama, emansipasi dalam kisah pewayangan, tidak semata mengenai tindakan mensejajarkan diri dengan kaum laki-laki, tetapi tindakan pemenuhan tugas dalam ranah domestik dan pengabdian secara psikologis (kesetiaan dan rela berkorban) juga termasuk wujud emansipasi kaum perempuan.

Kedua, bentuk emansipasi tokoh perempuan dapat berwujud pengabdian kepada suami, sebagai pemimpin bagi pihak lain, dan partner hidup laki-laki. Hal tersebut merupakan cerminan keseimbangan antara keberhasilan di ranah publik, dan pemenuhan tanggung jawab di ranah domestik.

Ketiga, hak memperoleh pendidikan maupun pelatihan, serta kesempatan berperan aktif di ranah publik bagi kaum perempuan telah tersirat dalam sastra pewayangan Mahabarata. Keempat, kisah pewayangan menunjukan wujud emansipasi yang ideal bagi masyarakat luas, baik dalam memberikan kontribusi di ranah publik maupun domestik, sehingga patut untuk dijadikan teladan dalam merekonstruksi pemahaman kaum perempuan terkait pemaknaan emansipasi dan kebebasannya. Di sisi lain, pemenuhan kewajiban antara ranah domestik dan kesempatan tampil di depan publik harus didukung oleh masyarakat melalui pembentukan kebijakan instansi yang sensitif gender. Mengingat keberadaan perempuan menjadi sosok yang akan berperan ganda di kedua sektor tersebut.

\section{Daftar Pustaka}

Azizah. Jiz (2011). The Gallant Woman From Java, Wanita Perkasa dari Tanah Jawa. In Azna Book. Yogyakarta.

Beauvoir, Simon De (2016). The Second Sex, Kehidupan Perempuan. Narasi. Yogyakarta.

Djarkasi, Agnes (2008). Woman in Publik Sector, Peranan Perempuan dalam Kesetaraan Gender, Suatu Tinjauan Historis di Sulawesi Utara. Tiara Wacana. Yogyakarta.

Hakim, M. Arief (2007) Pesan-pesan untuk Kaum Remaja. Regina. Bogor.
Hollows, Joanne. (2010). Feminisme, Feminitas, dan Budaya Populer. Jalasutra. Yogyakarta.

Kartono, Kartini. (2007). Psikologi Wanita, Mengenal Wanita Sebagai Ibu dan Nenek. Mandar Maju. Bandung.

Kurniawan, Haris (2010). Tendensi Sentral Pengarusutamaan Gender. Jembatan Ilmu. Surabaya.

Kuswanti, Herlina Dyah (2009). Gender and Politics, Kebijakan SDM di Tempat Kerja, Sudahkah Sensitif Gender?, Tiara Wacana. Yogyakarta.

Laksono, (2009). Tradisi dalam Struktur Masyarakat Jawa Kerajaan dan Pedesaan, Alih Ubah Model Berpikir Jawa. Kepel Press. Yogyakarta.

Lan, Thung $\mathrm{Ju}$ (2015). Perempuan dan Modernisasi. Jurnal Masyarakat dan Budaya Volume 17 No 1, Tahun 2015.

Purwadi, (2007). Mengenal Gambar Tokoh Wayang Purwa dan Keterangannya. Cendrawasih. Sukoharjo. Surakarta.

Sutardjo, (2007). Sejarah Wayang Purwa. Panji Pustaka. Yogyakarta.

Suwarno, (2016). Persepektif, Sebuah Catatan Pendidikan, Bahasa, Sastra dan Sosial Budaya. Azzagrafika. Sleman.

Wolfman, Brunetta, R (1992). Peran Kaum Wanita, Bagaimana Menjadi Cakap dan Seimbang dalam Aneka Peran. Kanisius. Yogyakarta.

Valentine, James Lee (2005). The Woman of Power, Menjadi Wanita Pemberdaya. Bhuana Ilmu Populer. Gramedia. Jakarta. 
